\title{
PENGARUH KRONIS INSEKTISIDA KLORPIRIFOS ETIL TERHADAP PERTUMBUHAN DAN STRUKTUR HATIIKAN NILA (Oreochromis niloticus)
}

\begin{abstract}
Imam Taufik
\section{ABSTRAK}

Penentuan konsentrasi kronis pestisida telah dilakukan di Laboratorium Instalasi Riset Lingkungan Perikanan Budidaya \& Toksikologi, Cibalagung dengan tujuan untuk mengetahui pengaruhnya terhadap pertumbuhan dan struktur hati ikan nila. Wadah yang digunakan berupa akuarium kaca berukuran $40 \times 20 \times 25 \mathrm{~cm}^{3}(\mathrm{p} \times \mathrm{I} \times \mathrm{t}$ ) yang diisi 10 liter air dan dilengkapi dengan aerasi. Hewan uji adalah ikan nila dengan bobot $2,75 \mathrm{~g} \pm 0,15 \mathrm{~g} / \mathrm{ekor}$ dan bahan uji berupa permulasi insektisida dengan kandungan bahan aktif $200 \mathrm{~g} / \mathrm{L}$ klorpirifos etil. Perlakuan berupa $0,232 \mathrm{mg} / \mathrm{L}$ selama 28 hari. Hasil bahan uji pada konsentrasi kronis yaitu: 0,$058 ; 0,116 ; 0,174$;

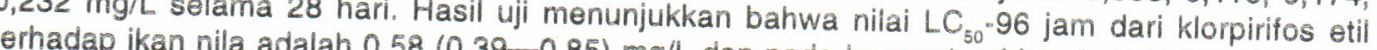
derhadap ikan nila adalah $0,58(0,39-0,85) \mathrm{mg} / \mathrm{L}$ dan pada konsentrasi kronis $0,116 \mathrm{mg} / \mathrm{L}$ sudah klorpirifos etil juga berpengaruh ikan nila secara berbeda nyata $(P<0,05)$. Konsentrasi kronis dipaparkan selama 28 hari sel heparnya mengalami piknosis, karioreksis, 0,$058 ; 0,116 ; 0,174$; dan $0,232 \mathrm{mg} / \mathrm{L}$, struktur sel-
\end{abstract}

ABSTRACT: The chronic effect of ethyl chlorpyrifos insecticides on growth and liver struc.
ture of tilapie. By: Imam Taufik

Study of pesticides chronic concentration was conducted at Fisheries Environmental Laboratory of Aquaculture Station in Cibalagung, to know the effect on growth and liver structure of tilapia. Aquarium with size of $40 \times 20 \times 25 \mathrm{~cm}^{3}$ with water volume of 10 liters, initial weight of fish $2.75 \pm$ $0.15 \mathrm{~g} / f \mathrm{ish}$, and pesticide active ingredient ethyl chlorpyrifos $200 \mathrm{~g} / \mathrm{L}$ were applied in this study. Fish exposed in different ingredient concentration e.g.: $0.58,0.116,0.174$, and $0.232 \mathrm{mg} / \mathrm{L}$ for 28 . days. The result showed the value of $L C_{50}-96$ hours ethyl chlorpyrifos was $0.58(0.39-0.85) \mathrm{mg} /$ $L$ and chronic concentration of $0.116 \mathrm{mg} / \mathrm{L}$ was able to significantly intervene the growth $(P<0.05)$. Chronic concentration of ethyl chlorpyrifos of $0.058,0.116,0.174$, and $0.232 \mathrm{mg} / \mathrm{L}$ with 28 hours exposure time was causing histopathological changes especially on liver cell structure i.e.: became pycnosis, caryorhexis, and cariolysis.

KEYWORDS: ethylchlorpyrifos, tilapie, $L C_{50}{ }^{a} 96$ hour

\section{PENDAHULUAN}

Indonesia sebagai negara yang berusaha meningkatkan produksi pangan telah banyak menggunakan pestisida pada sektor pertanian, bahkan menduduki urutan ketiga terbesar di Asia dalam penggunaan pestisida setelah RRC dan India (Koesoemadinata, 1980). Pestisida sebagai faktor tambahan telah digunakan untuk memanipulasi lingkungan dengan tujuan untuk memperbaiki kualitas lingkungan dan mengendalikan jasad pengganggu (hama) dan penyakit yang dapat menurunkan produksi (Wudianto, 1997).

Dampak penggunaan pestisida yang sering terabaikan adalah tercemarnya lingkungan perairan akibat jatuhnya bahan aktif pestisida ke dalam perairan. Oleh karena itu, pestisida dianggap sebagai sumber pencemar yang potensial bagi dunia perikanan. Menurut Sunarjo (1990), dalam konsentrasi yang tinggi bahan aktif pestisida yang masuk ke dalam air akan langsung mematikan ikan serta biota akuatik lainnya. Dalam konsentrasi yang rendah (kronis), meskipun tidak langsung mematikan tetapi dapat terakumulasi dalam jaringan tubuh, karena air, sedimen, dan biota akuatik (khususnya ikan, siput, dan kerang) merupakan media dan akumulator residu pestisida yang baik.

Klorpirifos adalah senyawa kimia yang banyak digunakan sebagai bahan aktif dalam formulasi insektisida untuk mengendalikan hama seperti Atherigona exiguna, Spodoptera maurua, Agrous sp. (Baehaki, 1993). Bahan aktif tersebut termasuk ke 
dalam golongan organofosfat yang bersifat tidak stabil dan lebih toksik terhadap hewan bertulang belakang dibanding dengan senyawa golongan organoklorin (Sastroutomo, 1992).

Ikan merupakan hewan yang sangat sensitif terhadap pencemaran pestisida. Tercemarnya ikan oleh pestisida terutama disebabkan oleh masuknya bahan aktif pestisida ke dalam media pemeliharaan (air) yang diserap oleh ikan melalui permukaan tubuh, insang, dan terbawa bersama makanan.

Ikan nila termasuk komoditas perikanan air tawar yang diprogramkan sebagai sumber protein hewani masyarakat. Kegiatan budi daya ikan nila banyak dilakukan di berbagai perairan seperti kolam, waduk, bahkan tambak air tawar. Perairan tersebut merupakan wilayah yang cukup rentan terhadap introduksi bahan aktif pestisida yang berasal dari berbagai aktivitas pertanian di lingkungan sekitarnya. Tercemarnya perairan oleh pestisida dengan konsentrasi yang tinggi akan mudah dideteksi dengan matinya berbagai organisme perairan termasuk ikan yang dibudidayakan, akan tetapi pencemaran pada konsentrasi rendah tidak dapat dideteksi secara visual tetapi hanya dapat dilakukan dengan deteksi analisis secara laboratoris. Oleh karena itu, informasi tentang pengaruh kronis insektisida dosis rendah terhadap ikan budi daya diperlukan untuk menjaga kesinambungan kegiatan budi daya serta mengantisipasi dampak pencemaran yang lebih buruk bagi kesehatan manusia.

\section{BAHAN DAN METODE}

Penelitian dilakukan di Instalasi Riset Lingkungan Perikanan Budidaya \& Toksikologi, Cibalagung-Bogor dengan menggunakan wadah berupa akuarium kaca berukuran $40 \times 20 \times 25 \mathrm{~cm}^{3}(p \times \mid \times t)$ yang diisi 10 liter air tawar dan dilengkapi dengan aerasi. Hewan uji yang digunakan adalah 1.000 ekor ikan nila dengan ukuran bobot 2,75 $\pm 0,15$ g/ekor yang berasal dari hasil pembenihan secara terkontrol. Sebelum digunakan hewan uji diaklimatisasikan terhadap kondisi laboratorium selama 14 hari dalam bak penampungan dan diberi pakan $10 \%$ dari bobot biomass/hari, kemudian diseleksi kelayakannya sebagai hewan uji.

Bahan yang digunakan adalah formulasi insektisida dengan kandungan bahan aktif $200 \mathrm{~g} / \mathrm{L}$ klorpirifos etil (selanjutnya ditulis klorpirifos) di mana bahan uji tersebut merupakan produk pestisida komersial yang sudah umum di pasar. Sebelum digunakan bahan uji sebanyak $1 \mathrm{~mL}$ dilarutkan dalam $10 \mathrm{~mL}$ aseton ditambah akuades hingga diperoleh larutan induk sebanyak $100 \mathrm{~mL}$ dengan konsentrasi $10.000 \mathrm{mg} / \mathrm{L}$.

\section{Uji Toksisitas Akut}

Uji toksisitas akut dilakukan untuk mencari nilai $\mathrm{LC}_{50}-96$ jam dari insektisida klorpirifos terhadap ikan nila yang akan digunakan sebagai dasar untuk menentukan konsentrasi perlakuan pada uji toksisitas kronis. Nilai $L_{5} C_{50}-96$ jam ditentukan dengan metode bioassay yang dilakukan melalui dua tahap (Busvine, 1971) sebagai berikut: Pertama, uji pendahuluan yaitu uji untuk menentukan ambang daya racun akut pestisida terhadap hewan uji dengan cara kisaran kritis (critical range), yaitu menentukan konsentrasi ambang bawah dan ambang atas yang berkisar antara 0,1; 1,0; dan 10 mg/L dengan waktu pemaparan selama 48 jam (Komisi Pestisida, 1983). Kedua, uji lanjutan yaitu untuk menentukan Median Lethal Concentration $\left(\mathrm{LC}_{50}\right)$ yang besarnya berada antara ambang bawah dan ambang atas yang nilainya dipilih secara berurutan berdasarkan deret logaritmik.

Rancangan percobaan yang digunakan adalah Rancangan Acak Lengkap (RAL) dengan 7 perlakuan konsentrasi dan 3 kali ulangan. Jumlah hewan uji dalam setiap bak bioassay sebanyak 10 ekor dengan waktu pemaparan 96 jam. Selama pemaparan hewan uji diberi pakan komersial (pelet) sebanyak 10\% dari bobot biomassa/hari.

Berdasarkan data mortalitas ikan uji pada setiap perlakuan setelah 96 jam pemaparan, maka ditentukan nilai $L_{50}$ dengan analisis probit yang mengacu pada metode Litchfield \& Wilcoxon (1949). Analisis dilakukan dengan mem-plot konsentrasi insektisida dengan mortalitas ikan pada grafik log probit (H.W. Peel and Co. Chartwell. Reg. No. 55/4), di mana mortalitas pada skala probit dan konsentrasi insektisida pada skala logaritma. Hasil plot pada garis menunjukkan persentase mortalitas harapan. Kemudian dilakukan koreksi antara mortalitas yang dicatat dengan mortalitas yang diharapkan melalui nilai (Chi) ${ }^{2}$ yang ditentukan dengan persamaan: dengan:

$$
(\text { Chi })^{2}=\left(M^{\prime}-M\right)^{2} / M^{\prime}\left(100-M^{\prime}\right)
$$

$M=$ mortalitas hewan uji tercatat atau dikoreksi

$M=$ mortalitas hewan uji yang diharapkan

Bila $(\mathrm{Chi})^{2}$ hitung $<(\mathrm{Chi})^{2}$ Tabel berarti heterogenitas data tidak nyata (letak garis grafik telah tepat) dan sebaliknya.

\section{Uji Toksisitas Kronis}

Uji toksisitas kronis dilakukan dengan tujuan untuk melihat pengaruh kronis dari klorpirifos terhadap pertumbuhan dan perubahan jaringan hati ikan nila. 
Penentuan konsentrasi kronis sebagai perlakuan didasarkan pada hasil uji toksisitas akut, yaitu: $10 \%$, $20 \%, 30 \%$, dan $40 \%$ dari nilai LC $50=96$ jam (Hastuti, 1985). Waktu pemaparan dilakukan selama 28 hari di mana selama periode tersebut dampak konsentrasi kronis dari pestisida sudah dapat terlihat dengan jelas (Murty, 1986). Selama pemaparan, hewan uji diberi pakan komersial secara at satiation (sampai kenyang).

\section{Pertumbuhan}

Untuk mengetahui pertumbuhan dilakukan pengukuran hewan uji setiap minggu dengan cara penimbangan total menggunakan timbangan Portable Standar Ohaus model Ls 2000 dengan tingkat ketelitian $0,01 \mathrm{~g}$. Pergantian air sebanyak $70 \%$ dilakukan setiap 48 jam dan pada saat sampling, menggunakan air dengan konsentrasi insektisida yang sesuai untuk setiap perlakuan.

Rancangan penelitian yang digunakan Rancangan Acak Lengkap (RAL) dengan tiga kali ulangan. Pertumbuhan individu mutlak (DW) dihitung menurut rumus Stickney (1979), yaitu:

$$
D W=w_{\hat{i}}-W_{0}
$$

dengan:

$D W=$ pertumbuhan individu mutiak $(g)$

$W_{t}=$ bobot hewan uji pada awal penelitian $(g)$

$W_{0}=$ bobot hewan uji pada akhir penelitian $(g)$

Laju pertumbuhan spesifik (Spesific Growih Rate) diukur dengan menggunakan rumus Steffen (1989):

$$
S G R=\ln W_{t}-\ln W_{0} / t_{1}-t_{0} x 100 x
$$

dengan:

$S G R=$ laju pertumbuhan harian $(\%)$

$W_{0}=$ bobot hewan uji pada awal penelitian (g)

$W_{t}=$ bobot hewan uji pada akhir penelitian $(g)$

$t_{0}=$ waktu awal penelitian (hari)

$t_{1}=$ waktu akhir penelitian (hari)

Terhadap data yang diperoleh dilakukan analisis statistik pada taraf kepercayaan $95 \%$ dan $99 \%$ yang dilanjutkan dengan uji Duncan untuk mengetahui pengaruh antar perlakuan.

\section{Pengamatan histologi}

Terhadap hewan uji yang telah dipaparkan selama 28 hari dalam masing-masing perlakuan, dilakukan pengamatan histologi pada struktur jaringan hati yaitu dengan membuat preparasi/sediaan histologi dengan metode parafin dan pewamaan Harris Haemotoxylin \& Eosin (HE). Pengamatan preparasi dilakukan menggunakan mikroskop cahaya (foto mikro) pada pembesaran 400 kali dengan cara membandingkan preparasi dari setiap perlakuan dengan kontrol.

\section{Kualitas air}

Karakteristik fisika-kimia air selama penelitian diusahakan supaya memenuhi kriteria bagi pengujian toksisitas ikan (APHA, 1981). Oleh karena itu, dilakukan pengukuran beberapa parameter kualitas air secara periodik yang meliputi: suhu air, oksigen teriarut, $\mathrm{pH}, \mathrm{CO}_{2}$ bebas, $\mathrm{NH}_{3}$, Kesadahan total, dan konduktivitas.

\section{HASIL DAN BAHASAN}

\section{Toksisitas akut}

Dari hasil uji pendahuluan diketahui bahwa kisaran kritis insektisida klorpirifos terhadap ikan nila adalah antara $0,1 \mathrm{mg} / \mathrm{L}$. (LC $048 \mathrm{jam}$ ) dan 1,0 mg/L. (LC 1900.24 jam). Berdasarkan kisaran tersebut, maka deret loganimik Duoduroff et al. (1951) konsentrasi klorpiritos yang dipilih pada uji lanjutan adalah: 0,$42 ; 0,56 ; 0,75$; 1,$00 ; 1,35$; dan $1,80 \mathrm{mg} / \mathrm{L}$ dan kontrol (tanpa kiorpirifos) sebagai pembanding dan data mortalitas ikan nila pada masing-masing konsentrasi rersebut setelah 96 jam pemaparan disajikan pada Tabel 1.

Hasil uji normalitas, aditivitas, dan homogenitas terhadap mortalitas ikan nila menunjukkan data menyebar normal, bersifat additive dan homogen. Melalui analisis ragam menunjukkan bahwa $F$ hitung $>\mathrm{F}$ tabel $(1 \%)$ yang berarti di antara rata-rata mortalitas perlakuan terdapat perbedaan yang sangat nyata. Hasil uji terhadap mortalitas ikan ternyata perlakuan konsentrasi $1,80 \mathrm{mg} / \mathrm{L}$ berbeda nyata dengan $1,35 \mathrm{mg} / \mathrm{L}$ dan berbeda sangat nyata dengan kontrol; 0,$42 ; 0,56 ; 0,75$; dan $1,00 \mathrm{mg} / \mathrm{L}$. Konsentrasi $1,35 \mathrm{mg} / \mathrm{L}$ berbeda nyata dengan konsentrasi 0,56 $\mathrm{mg} / \mathrm{L}$ dan $0,42 \mathrm{mg} / \mathrm{L}$ serta berbeda sangat nyata dengan kontrol. Konsentrasi 0,$56 ; 0,75$; dan $1,00 \mathrm{mg} /$ $L$ berbeda sangat nyata dengan kontrol. Hal ini menunjukkan bahwa insektisida klorpirifos mempunyai daya racun tinggi (toksik) karena dengan konsentrasi yang relatif rendah yaitu sebesar $0,56 \mathrm{mg} /$ $\mathrm{L}$, sudah menimbulkan efek yang mematikan terhadap ikan nila.

Melalui analisis probit dari nilai-nilai konsentrasi klorpirifos dan mortalitas ikan nila diketahui bahwa nilai $\mathrm{LC}_{50}-96 \mathrm{jam}$ adalah sebesar $0,56(0,39-0,85)$ $\mathrm{mg} / \mathrm{L}$ di mana pada konsentrasi tersebut montalitas ikan nila menunjukkan persentase tepat pada skala probit $50 \%$. Jika diklasifikasikan berdasarkan daya racun pestisida terhadap ikan (Komisi pestisida, 1983) 
Tabel 1. Mortalitas ikan nila pada setiap konsentrasi perlakuan setelah pemaparan

Table 1. Mortality of tilapia in each treatment during exposure time

\begin{tabular}{|c|c|c|c|}
\hline \multirow{2}{*}{$\begin{array}{c}\text { Konsentrasi } \\
\text { Concentration } \\
(\mathrm{mg} / \mathrm{L})\end{array}$} & \multirow{2}{*}{$\begin{array}{l}\text { Jumlah ikan (ekor) } \\
\text { Number of fish (fish) }\end{array}$} & \multicolumn{2}{|c|}{ Mortalitas (Mortality) } \\
\hline & & $\begin{array}{l}\text { Jumlah (ekor) } \\
\text { Number (fish) }\end{array}$ & $\begin{array}{c}\text { Persentase } \\
\text { Percentage (\%) }\end{array}$ \\
\hline Kontrol (Control) & 30 & 0 & $0.00^{a}$ \\
\hline 0.42 & 30 & 13 & $43.33^{a b}$ \\
\hline 0.56 & 30 & 14 & $46.67^{b}$ \\
\hline 0.75 & 30 & 17 & $56.67^{b c}$ \\
\hline 1.00 & 30 & 18 & $60.00^{b c}$ \\
\hline 1.35 & 30 & 21 & $70.00^{\mathrm{c}}$ \\
\hline 1.80 & 30 & 28 & $93.33^{d}$ \\
\hline
\end{tabular}

*) Angka pada kolom sama yang diikuti huruf sama menunjukkan tidak beda nyata $(P>0,05)$

Mean value in the same column followed by the same subscript are not significantly different $(P>0.05)$

maka klorpirifos termasuk ke dalam insektisida dengan tingkat daya racun sangat tinggi dengan nilai $\mathrm{LC}_{50}{ }^{-96}$ jarn $<1 \mathrm{mg} / \mathrm{L}$. Tingginya toksisitas ini berkaitan erat dengan sifat dari insektisida tersebut yang termasuk ke dalam golongan organofosfat yang mempunyai sifat sangat cepat dan efektif menyerang sistem syaraf dan menyebabkan inaktifnya asetilkholinesterase yang berperan untuk mengatur pemindahan impuls syaraf (Ewen \& Stephensons, 1977 dalam Darmiatun, 1993).

Kematian ikan nila pada uji toksisitas akut terjadi akibat masuknya insektisida ke dalam tubuh melalui difusi kulit, mulut, saluran pernafasan, dan saluran pencernaan. Insektisida secara kimiawi akan mengikat enzim asetilkhlolinesterase yang berfungsi mengatur kerja syaraf. Bila enzim yang berada dalam darah tersebut terikat maka kerja syaraf menjadi terganggu akibatnya pergerakan otot tidak dapat dikendalikan sehingga timbul ketegangan, lumpuh, dan pingsan sampai menyebabkan kematian (Natawiguna, 1989).

\section{Toksisitas kronis}

Pengaruh kronis adalah pengaruh yang merusak bagian fisiologis atau perilaku tetapi tidak menyebabkan kematian langsung meskipun kematian dapat terjadi karena gangguan terhadap proses makan, pertumbuhan, atau perilaku yang tidak normal, lebih mudah ditangkap mangsanya, kurangnya kemampuan mengkoloni atau sebab-sebab lain yang tidak langsung. Pengaruh ini tidak hanya menyebabkan perubahan dalam populasi spesies individu tetapi juga menyebabkan pergeseran komposisi dan diversifikasi spesies (Connel \& Miller, 1995). Konsentrasi kronis pestisida dalam perairan akan menimbulkan efek terhadap ikan antara lain: kecepatan dan pola pertumbuhan, terganggunya fungsi-fungsi patofisiologis tubuh serta adanya perubahan- perubahan patomorfologi baik morfologi luar ikan maupun gangguan jaringan (histologi) atau sel (sitologi) (Mitrovic, 1972 dalam Putranto, 1994).

Pada konsentrasi klorpirifos yang rendah ikan nila akan mampu mempertahankan kondisi homeostasi, apabila konsentrasi dinaikkan akan timbul kompensasi dan dalam hal ini fungsi organ masih mungkin bekerja, tetapi jika konsentrasi semakin tinggi akan menyebabkan ikan nila menjadi stres dan mengalami gangguan fisiologis.

\section{Pertumbuhan}

Perubahan karakteristik biologik yang penting seperti kecepatan pertumbuhan merupakan salah satu parameter efek kronis bahan pencemar terhadap ikan (Mitrovic, 1972 dalam Putranto, 1994). Hal tersebut terbukti dari hasil pengukuran pertambahan bobot ikan nila pada masing-masing perlakuan selama 28 hari pemaparan (Gambar 1).

Secara umum dapat dikatakan bahwa insektisida klorpirifos pada semua konsentrasi perlakuan akan menghambat pertumbuhan ikan nila. Hal ini semakin nyata ketika konsentrasi mencapai 0,116 mg/L (20\% dari nilai $\mathrm{LC}_{50}-96$ jam) di mana pada minggu pertama pemaparan sudah menghambat pertambahan bobot ikan nila dan dengan meningkatnya konsentrasi perlakuan maka semakin rendah pertumbuhannya.

Hasil analisis statistik menunjukkan bahwa pada perlakuan konsentrasi $0,116 \mathrm{mg} / \mathrm{L}$ atau lebih, sudah dapat menurunkan pertumbuhan mutlak serta laju pertumbuhan spesifik ikan nila yang berbeda nyata $(\mathrm{P}<0,05)$ dengan kontrol, bahkan pada konsentrasi $0,174 \mathrm{mg} / \mathrm{L}$ dan $0,232 \mathrm{mg} / \mathrm{L}$ berbeda sangat nyata $(P<0,01)$ dengan kontrol, perlakuan konsentrasi 0,116 mg/L dan 0,174 mg/L juga memberikan pengaruh yang 


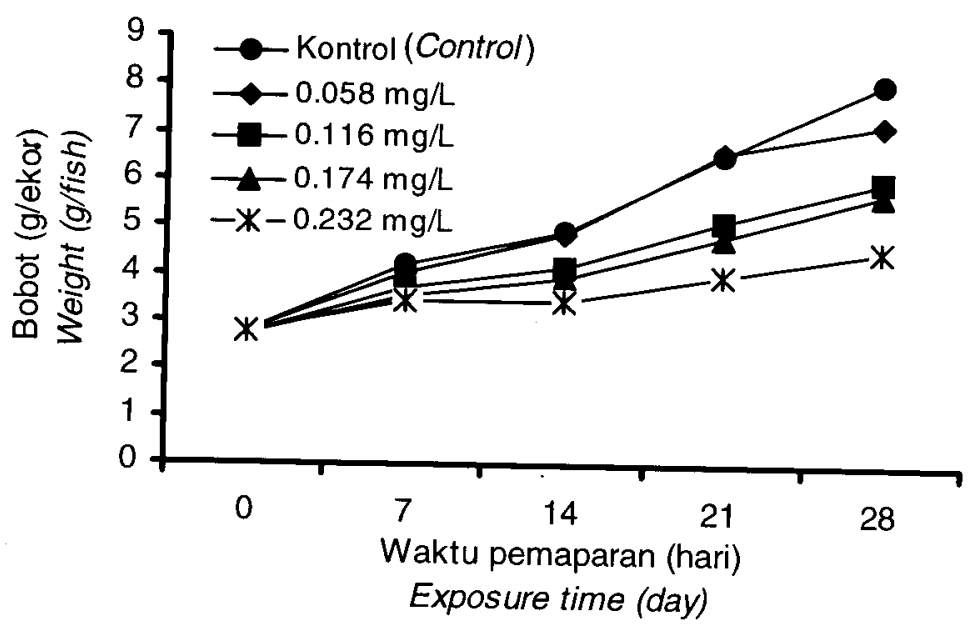

Gambar 1. Pertambahan bobot rata-rata individu (g/ekor) ikan nila pada setiap konsentrasi perlakuan selama
pemaparan

Figure 1. Weight gain of tilapia (g/fish) in each treatment during exposure time

Tabel 2. Pertumbuhan mutlak (DW) dan laju pertumbuhan spesifik (SGR) ikan nila pada masing-masing konsentrasi perlakuan selama pemaparan

Table 2. Total growth and spesific growth rate of tilapia in each treatment

\begin{tabular}{ccc}
\hline $\begin{array}{c}\text { Konsentrasi (Concentration) } \\
\text { (mg/L) }\end{array}$ & $\begin{array}{c}\text { DW }^{\star} \\
(\mathbf{g})\end{array}$ & $\begin{array}{c}\text { SGR }^{\star} \\
(\%)\end{array}$ \\
\hline Kontrol (Control) & $5.32 \pm 0.55$ & $3.84 \pm 0.21^{\mathrm{a}}$ \\
0.058 & $4.42 \pm 0.39$ & $3.41 \pm 0.22^{\mathrm{ab}}$ \\
0.116 & $3.30 \pm 0.55$ & $2.84 \pm 0.38^{\mathrm{b}}$ \\
0.174 & $3.00 \pm 0.26$ & $2.63 \pm 0.21^{\mathrm{b}}$ \\
0.232 & $1.78 \pm 0.97$ & $1.77 \pm 0.51^{\mathrm{c}}$ \\
\hline
\end{tabular}

*) Angka pada kolom yang sama diikuti huruf sama menunjukkan tidak berbeda nyata $(P>0,05)$ Mean value in same column followed by the same subscript are not significantly different $(P>0.05)$

berbeda nyata $(P<0,05)$ dengan konsentrasi 0,232 $\mathrm{mg} / \mathrm{L}$ (Tabel 1).

Terhambatnya pertumbuhan ikan nila disebabkan energi yang diperoleh dari makanan lebih banyak digunakan untuk mempertahankan diri dari tekanan lingkungan yang buruk (toksik) daripada untuk pertumbuhan. Menurut Waren (1971), secara normal sekitar $70 \%$ nilai energi yang berasal dari makanan diprioritaskan dan dipergunakan untuk pemeliharaan (maintenance) jaringan tubuh, tetapi apabila ikan sakit atau mengalami gangguan lingkungan, maka penggunaan energi untuk mempertahankan hidup lebih besar dari biasanya.

Hambatan terhadap pertumbuhan ikan juga dapat terjadi karena perubahan patomorfologi, baik morfologi luar ikan maupun gangguan histologi sehingga sistem kerja organ dalam menjadi rusak dan proses fisiologis ikan terganggu, hal ini terbukti dari hasil pengamatan mikro-anatomi terhadap jaringan hepar ikan nila yang tampak mengalami kerusakan setelah pemaparan.

\section{Pengamatan histologi}

Pengamatan ditujukan untuk melihat pengaruh toksisitas kronis insektisida klorpirifos terhadap kerusakan organ dalam ikan. Organ dalam yang diamati adalah hati, karena organ ini selain berhubungan dengan pengaturan substansi kimia di dalam aliran darah juga mempengaruhi fungsi metabolik yang kompleks (Marshall \& Hughes, 1980 dalam Sarjono, 1995).

Dari hasil pengamatan ditemukan adanya perbedaan struktur hati antara ikan nila pada kontrol dengan semua perlakuan. Hati tersusun atas sel-sel yang disebut hepatosit yang berbentuk polihedral dengan satu nukleus di dalamnya yang berbentuk bulat dan terletak di tengah-tengah serta mempunyai satu nukleus yang tampak lebih gelap. Eritrosit yang terdapat dalam sinusoid-sinusoid hati berbentuk oval dengan nukleus berbentuk oval pula. Pada kontrol struktur hati terlihat kompak (masif) dengan hubungan antara sel tampak rapat satu dengan lainnya (Gambar 
2) sedangkan pada perlakuan konsentrasi 0,058 ; 0,116; 0,174; dan 0,232 mg/Lterlihat adanya hepatosit yang mengalami piknosis (penebalan, terutama degradasi sel yang intinya mengkerut, dan kromatinnya memadat menjadi massa mampat tanpa struktur), karioreksi (pecahnya inti sel disertai disintegrasi kromatinnya menjadi granulair yang kemudian dikeluarkan dari sel) dan kariolisis (pencairan inti sel) (Gambar 3).

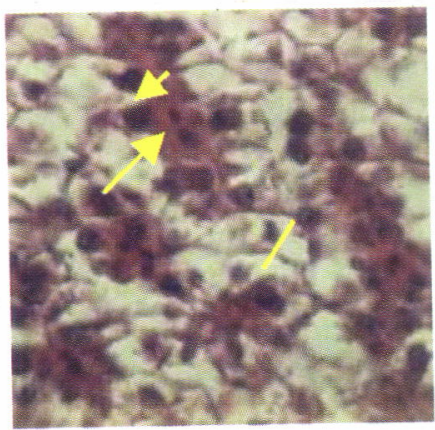

Gambar 2. Kontrol (0 mg/L); nukleus (kepala panah); eritrosit (panah); hepatosit (garis)

Figure 2. Control (0 mg/L); nucleus (arrow head); eritrocyt (arrow); hepatocyt (line)

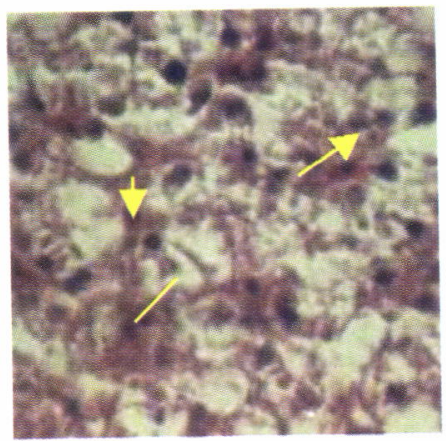

(0.058 mg/L)

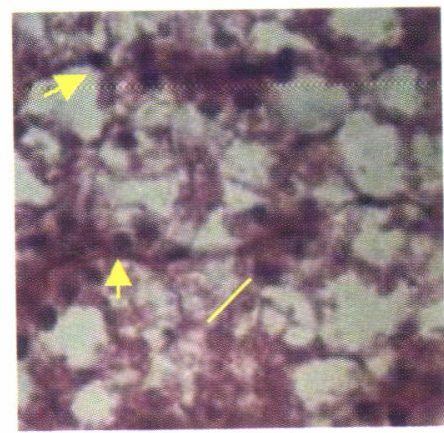

(0.174 mg/L)

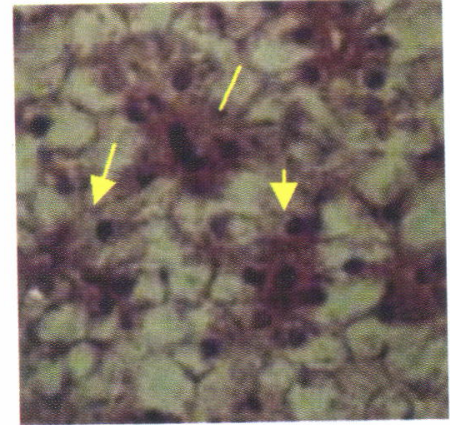

(0.116 mg/L)

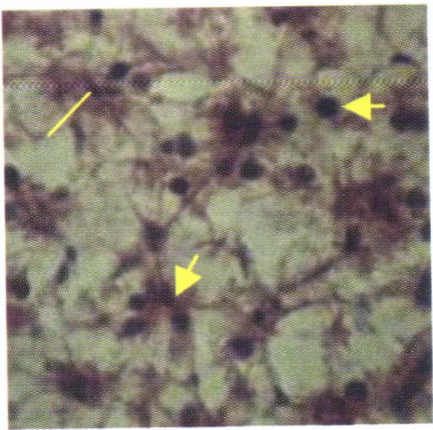

(0.232 mg/L)

Gambar 3. Sel hati yang mengalami piknosis (kepala panah), karioreksis (garis) dan kariolisis (panah) Figure 3. Pycnosis (arrow head), cariorexys (line) and cariolysis (arrow) cells in liver

Degradasi lemak yang dicirikan dengan adanya xirosis (adanya rongga antar sel yang tadinya berisi lemak) terjadi karena masuknya bahan aktif klorpirifos ke dalam hati bersama aliran darah dan mempengaruhi/merusak hepatosit. Dalam keadaan normal hepatosit terlibat aktif dalam metabolisme lemak yang secara terus-menerus dimobilisasi dari jaringan adipose ke dalam darah, akhirnya masuk ke sel hati yang sebagian akan dioksidasi dan sebagian lagi akan disintesis menjadi lipoprotein. Selanjutnya dikeluarkan dari dalam sel atau diubah menjadi asam lemak dan disimpan dalam sel hati itu sendiri (Prince \& Wilson, 1984 dalam Sarjono, 1995). Kematian selsel hati yang ditandai dengan nukleus piknosis, karioreksis, dan kariolisis diduga karena adanya gangguan kerja berbagai enzim yang bekerja dalam 
sel sehingga metabolisme sel terganggu dan kematian sel terjadi pada eritrosit yang ada pada sinusoid.

\section{Kualitas air}

Selama penelitian berlangsung, media uji cukup mendukung bagi kehidupan ikan nila, terbukti dari hasil pengukuran sifat fisika-kimia air yang masih dalam kondisi layak dengan nilai kisaran sebagai berikut: suhu air $25^{\circ} \mathrm{C}-27^{\circ} \mathrm{C}$; pH 6,7-8,2; oksigen terlarut $6,6-8,2 \mathrm{mg} / \mathrm{L}$; alkalinitas $68,4-171,1 \mathrm{mg} / \mathrm{L}$; kesadahan 38,09-60,60 mg/L; dan amonia 0,037$0,115 \mathrm{mg} / \mathrm{L}$. Dengan demikian dapat dikatakan bahwa media uji tidak menjadi faktor pembatas bagi hewan uji.

\section{KESIMPULAN}

Dari pembahasan data hasil penelitian di atas, dapat diambil beberapa kesimpulan sebagai berikut:

1. Kisaran kritis insektisida klorpirifos terhadap ikan nila adalah antara $0,1 \mathrm{mg} / \mathrm{L}$ dan $1,0 \mathrm{mg} / \mathrm{L}$ dengan nilai $L C_{50}-96$ jam sebesar $0,58(0,39-0,85) \mathrm{mg} / \mathrm{L}$.

2. Berdasarkan klasifikasi daya racun pestisida terhadap ikan, klorpirifos termasuk insektisida berdaya racun sangat tinggi dengan nilai $\mathrm{LC}_{50}-96$ jam < $1 \mathrm{mg} / \mathrm{L}$.

3. Konsentrasi insektisida klorpirifos dalam air sebesar $0,116 \mathrm{mg} / \mathrm{L}\left(20 \%\right.$ dari nilai $\left.\mathrm{LC}_{50}-96 \mathrm{jam}\right)$ sudah dapat menghambat pertumbuhan ikan.

4. Insektisida klorpirifos pada konsentrasi $0,58 \mathrm{mg} / \mathrm{L}$ atau lebih memberi pengaruh buruk terhadap struktur hati ikan nila yang mengakibatkan pembengkakan hepatosit, serta hepatosit yang mengalami piknosis, karioreksis, dan kariolisis.

\section{DAFTAR PUSTAKA}

APHA, AWWA dan WPCF. 1981. Standard Method for EXamination of Water and Waste Water. 15 th. Edition. APHA. Woshington, p. 685-740.

Baehaki, 1993. Insektisida Pengendali Hama Tanaman. Angkasa Bandung, 45 pp.

Busvine, J.R. 1971. Antificial Review of Techniques for Testing Insecticides. Common Wealth Agricultural Boreoux, $345 \mathrm{pp}$.
Connel, D.W. dan G.J. Miller. 1995. Kimia dan Ekotoksikologi Pencemaran (penterjemah Y. Koestoer). UI Press. Jakarta, 520 pp.

Darmiatun, S. 1993. Toksisitas, Efek Patologik dan Kandungan Pb Asetat dan Zn Asetat pada Ikan Nila (Oreochromis niloticus, Trewavas). Skripsi. Fakultas Biologi-UGM. Yogyakarta, 59 pp.

Duoduroff, T., B.G. Anderson, C.E. Burdick, P.S. Galtsoff, W.B. Hart, R. Patrick, E.R. Strong, E.W. Surber, and W.M. Van Horn. 1951. Bioassay method for the evaluation of acute toxicity of industrial wastes to fish. Sewage and Industrial Wastes, 23(11): 1,380-1,397.

Hastuti, W. 1985. Pengaruh kronis konsentrasi kronis detergen terhadap pertumbuhan dan produksi ikan nila. Skripsi. Fakultas Pertanian, IPB-Bogor, 78 pp.

Koesoemadinata, S. 1980. Pesticides as a mayor counstrain to integrated agricultural - Aquac. Farm. Syst. In. Pullin, R.S.V., dan Shehaheh, Z.H. Integrated Agricultural Farming System. ICLARM Conference Proceeding, 4: 45-52.

Komisi Pestisida. 1983. Pedoman Umum Pengujian Laboratorium Toksisitas Letal Pestisida pada Ikan untuk Keperluan Pendaftaran. Departemen Pertanian. Jakarta, 24 pp.

Litchfield, Jr.J.T. and F. Wilcoxon. 1949. A simplified method of evaluation dose-effect experiments. $J$. Phar. Exp. Therap, 56: 89-113.

Murty, A.S. 1986. Toxicity of Persticides to Fish. CRC Press Inc. Boca Raton, Florida, 1: 86.

Natawiguna, H. 1989. Pestisida dan Kegunaannya. Amrico, Bandung, 95 pp.

Sarjono, F. 1995. "Toksisitas serta pengaruh patologik kronis insektisida Chemition 500 EC terhadap ikan tombro (Cyprinus carpio L.)". Fakultas Biologi - UGM. Yogyakarta. (Tidak dipublikasikan).

Sastroutomo, S.S. 1992. Pestisida, Dasar-dasar dan Dampak Penggunaannya. Gramedia Pustaka Utama. Jakarta, 47 pp.

Stickney, R.R. 1979. Principal of Warm Water Aquaculture. John Willey and Sons. New York, $237 \mathrm{pp}$.

Sunarjo, P.I. 1990. Dampak pestisida pada biota perairan. Tinjauan Hasil Penelitian Jurusan Hama dan Penyakit Tumbuhan. Fakultas Pertanian Univ. Hasanuddin. Ujung Pandang, 14 pp.

Warren, C.E. 1971. Biology and Water Pollution Control. W.B. Sounders Co. Philadelpia, p. 67-113.

Wudianto, R. 1997. Petunjuk Penggunaan Pestisida. Penebar Swadaya. Jakarta, 35 pp. 
